\title{
Phytoprotection
}

\section{Occurrence of paracrystalloids and their particles in resistant and susceptible carnation plants infected with Fusarium oxysporum f.sp. dianthi race 2 \\ Étude comparative de la présence de corps cristallins et de leurs particules dans des plants d'oeillet sensibles ou résistants à l'infection par le Fusarium oxysporum f.sp. dianthi race 2}

\author{
Guillemond B. Ouellette, Danny Rioux, Marie Simard et Robert P. Baayen
}

Volume 85, numéro 3, décembre 2004

URI : https://id.erudit.org/iderudit/010906ar

DOI : https://doi.org/10.7202/010906ar

Aller au sommaire du numéro

Éditeur(s)

Société de protection des plantes du Québec (SPPQ)

ISSN

0031-9511 (imprimé)

1710-1603 (numérique)

Découvrir la revue

Citer cet article

B. Ouellette, G., Rioux, D., Simard, M. \& P. Baayen, R. (2004). Occurrence of paracrystalloids and their particles in resistant and susceptible carnation plants infected with Fusarium oxysporum f.sp. dianthi race 2. Phytoprotection, 85(3), 139-151. https://doi.org/10.7202/010906ar

\section{Résumé de l'article}

Des structures cristallines opaques formées de particules singulières (d'environ 20-22 nm en diamètre désignées OP) ont été observées uniquement dans le voisinage de cellules colonisées dans des plants d'oeillet sensibles ou résistants à l'infection par le Fusarium oxysporum f.sp. dianthi. Dans les plants sensibles, les OPs se trouvaient dans les éléments de vaisseaux et les parois cellulaires, et rattachées à l'altération de celles-ci, mais elles étaient absentes dans les cellules de parenchyme du xylème. Par contre, dans les plants résistants, les OPs ne se trouvaient que dans ces cellules. En comparaison avec des structures vraisemblablement similaires rapportées pour d'autres systèmes, les OPs et les corps cristallins semblent tout à fait différents de ceux observés dans des plantes atteintes de virus ou de champignons, mais montrent une similitude avec des corps observés dans des plants parasités par des nématodes. Les OPs ont montré un rapport évident avec de la matière opaque, souvent parsemée de structures filamenteuses dans les plants des deux cvs., et en plus avec des cellules de l'agent pathogène dans le cas du cv. sensible. Des structures semblables se trouvaient souvent dans les parois de l'hôte, reliant en quelque sorte les cellules, incluant les cellules de parenchyme dans les plants résistants; ainsi, les OPs et les corps crystallins dans ces cellules semblaient pouvoir se rattacher à ces filaments comme dans les plants sensibles. En raison de l'affinité entre la matière opaque, les structures filamenteuses et les OPs, et de chacun de ces éléments avec les cellules fongiques, il a semblé pertinent d'attribuer la genèse des particules à l'agent pathogène. 


\title{
Occurrence of paracrystalloids and their particles in resistant and susceptible carnation plants infected with Fusarium oxysporum f.sp. dianthi race 2
}

\author{
Guillemond B. Ouellette', Danny Rioux', Marie Simard1', and Robert P. Baayen²
}

Received 2005-02-07; accepted 2005-04-08

PHYTOPROTECTION $85: 139-151$

Uncommon, opaque particles (of approximately 20-22 nm, referred to as OP), aggregating into paracrystalloids occurred only next to colonized cells in carnation plants of either a susceptible or resistant cultivar (cv.) infected with Fusarium oxysporum f.sp. dianthi. In the susceptible plant, those structures occurred in vessel lumina and host walls, apparently associated with their alterations, but not in parenchyma cells, a situation which was the exact opposite of that observed in resistant plants. In comparison with apparently similar structures reported in other systems, paracrystalloids and their OPs did not seem to have exact counterparts in plants infected with viruses or fungi, although similar paracrystalloids were observed in nematode-infected plants. The OPs were associated in both cvs. with fine opaque matter, often displaying fine filamentous structures, and were in addition connected to fungal cells in the susceptible cv. Similar structures also extended through host walls into adjoining cells; these relations with parenchyma cells in resistant plants were interpreted as if the particles therein were akin to, if not exactly of the same nature as those in susceptible plants. As the opaque matter, the filamentous structures and the OPs were interrelated and associated with pathogen cells, it seemed warranted to assume that the OPs were issued from the pathogen.

[Étude comparative de la présence de corps cristallins et de leurs particules dans des plants d'œillet sensibles ou résistants à l'infection par le Fusarium oxysporum f.sp. dianthi race 2]

Des structures cristallines opaques formées de particules singulières ( $d$ 'environ 20-22 nm en diamètre désignées $\mathrm{OP}$ ) ont été observées uniquement dans le voisinage de cellules colonisées dans des plants d'œillet sensibles ou résistants à l'infection par le Fusarium oxysporum f.sp. dianthi. Dans les plants sensibles, les OPs se trouvaient dans les éléments de vaisseaux et les parois cellulaires, et rattachées à l'altération de celles-ci, mais elles étaient absentes dans les cellules de parenchyme du xylème. Par contre, dans les plants résistants, les OPs ne se trouvaient que dans ces cellules. En comparaison avec des structures vraisemblablement similaires rapportées pour d'autres systèmes, les OPs et les corps cristallins semblent tout à fait différents de ceux observés dans des plantes atteintes de virus ou de champignons, mais montrent une similitude avec des corps observés dans des plants parasités par des nématodes. Les OPs ont montré un rapport évident avec de la matière opaque, souvent parsemée de structures filamenteuses dans les plants des deux cvs., et en plus avec des cellules de l'agent pathogène dans le cas du cv. sensible. Des structures semblables se trouvaient souvent dans les parois de l'hôte, reliant en quelque sorte les cellules, incluant les cellules de parenchyme dans les plants résistants; ainsi, les OPs et les corps crystallins dans ces cellules semblaient pouvoir se rattacher à ces filaments comme dans les plants sensibles. En raison de l'affinité entre la matière opaque, les structures filamenteuses et les OPs, et de chacun de ces éléments avec les cellules fongiques, il a semblé pertinent d'attribuer la genèse des particules à l'agent pathogène.

1. Natural Resources Canada, Canadian Forest Service, Laurentian Forestry Centre, P.O. Box 3800, Sainte-Foy (Québec), Canada G1V 4C7. Corresponding author e-mail: gouellette@cfl.forestry.ca

2. Research Institute for Plant Protection, P.O. Box 9060, 6700 GW Wageningen, The Netherlands; present address: Plant Protection Service, P.O. Box 9102, 6700 HC Wageningen, The Netherlands. 


\section{INTRODUCTION}

Histopathological and cytochemical studies of fusarium wilt of carnation (Dianthus caryophyllus L.) have shown marked differences between plants of a susceptible cv. and those of a resistant one, inoculated with the same pathogen isolate, Fusarium oxysporum Schlechtend.:Fr. f.sp. dianthi (Prill. \& Delacr.) Snyder \& Hans. race 2 (Baayen et al. 1996; Ouellette et al. 1999a, 2002, and citations therein). One main difference was the confinement of the pathogen by host cell wall modifications and barrier zone formation in resistant plants as compared with its extensive intercellular invasion in the susceptible plants, favoured by the lack of similar wall modifications. The deposition of layers or patches of opaque matter on vessel walls occurred in both types of plants.

Another characteristic feature of infection specific to susceptible plants was the eventual occurrence, in primary walls and middle lamella of invaded vessel elements, of numerous opaque particles (referred to hereafter as OP), and their aggregations into paracrystalloids (Ouellette and Baayen 2000); these were absent in parenchyma cells. In the resistant plants, a reverse situation was observed, with numerous similar OPs and paracrystalloids found only in paratracheal cells (Ouellette et al. 2002). In that article, the illustrations of these structures were shown at low magnifications, making it difficult to pinpoint the particle arrangements and to describe accurately how they differed from normal host cell content.

Another yet undescribed feature concerned the occurrence in the susceptible plants of similar particles and aggregates in vessel elements, and their connections with fungal cells. For the present study, our goal was to describe more broadly the occurrence of these structures in cell walls and vessel lumina in the susceptible plants, in comparison with their different occurrence in the resistant plants, including indications of their possible origin and significance in the infection process. This work is a complement to reports of other types of matter present on vessel walls in the susceptible plants (Ouellette et al. 2004a).

\section{MATERIALS AND METHODS}

They are described in Ouellette et al. (2004a). Some of the photomicrographs presented here are from sections labelled for pectin (Ouellette et al. 1999a) but this labelling was not presented for purposes related to this study.

\section{RESULTS}

\section{Susceptible plants}

In early infection (Ouellette et al. 1999a), vessel walls became coated with layers of opaque matter. Some of this material contained small particles which were initially suspected to correspond to remnants of host vessel cytoplasm, although these particles were mixed with structures that seemed associated with vessel wall alterations (Fig. 1a); the possible relationship of these structures to fungal cells was similarly not investigated. Likewise, as the coating generally appeared as homogeneous, opaque matter (Fig. 1b), it was not frequently scrutinized at higher magnifications. Then, these particles (referred to hereafter as OPs) were noticed at different but mostly later stages of infection in lumina and on walls of vessels, associated with their alterations, and forming aggregates (Fig. 1c-e). The coating was often confluent with the outer opaque layer of fungal cells (Fig. 1e). Fine filamentous structures were noticeable that extended through these walls and into the host walls (Fig. 1e). Similar filaments also extended from intercellular fungal cells into host walls reaching vessel lumina (Fig. 1c, d) and bridged the occasionally localized additional fungal wall layers with their outer opaque layer (Fig. 1f).

Rows or confluent masses of OPs were closely connected to fungal walls by means of filamentous structures (Fig. 2a, b). The OPs were also frequently mixed with fine opaque material (Figs. 1d, 2b, 3a-b) that, in the clearest cases, likewise displayed filamentous structures (Fig. 2c). Vessel lumina often contained numerous OPs that were occasionally bound to membranous structures (Fig. 3b). Compared with the more opaque particles of the gold-complexed probes, OPs were less opaque and slightly larger (15 vs. $20-22 \mathrm{~nm}$; see in particular the OPs included in the vessel wall overlaid with gold particles, Fig. 3b). Cross sections of the aggregates have shown them to be formed of spherical units, embedded in fine material, (Figs. 1d, 2c, 3b). These aggregates were frequently arranged in non-parallel arrays that formed paracrystalloids (Figs. 1d, 3b).

As mentioned above, the masses of matter appearing as homogeneously opaque at low magnifications and contrast were shown to be a mixture of OPs and fine material. A similar association was observed in invaded vessel walls and adjoining parenchyma cell walls (Fig. 3c, d). This matter frequently spanned long distances in the walls, connected to fungal cells having thin and locally chitinlabelled walls or bordered by unlabelled bands (Fig. $3 e$ ). It also occurred in the vicinity of chitin-labelled large or irregular fungal cells (Figs. 3e, 4).

OPs and crystalline bodies were not detected in intact or altered host cell content, except in the immediate presence of pathogen cells (Fig. 5a-e). Even then, areas showing strongly degraded host cell contents in severely altered tissue, mostly in newly differentiated cells, could be distinguished from the OP-containing areas (Fig. 5c, e). Often, masses of OPcontaining material extended over long distances, and could have been interpreted as being part of a host cell. However, this material was shown to be intraparietal (Fig. 5c). Individual parenchyma cells containing numerous OPs, similar to those surrounding fungal cells and free of other normal cytoplasmic structures, were only exceptionally observed in susceptible plants (Fig. 6a, b). The presence of similar OPs in the pathogen cells was not detected, but globoid bodies, twice as large as OPs, were sometimes observed therein (Fig. 6c). 


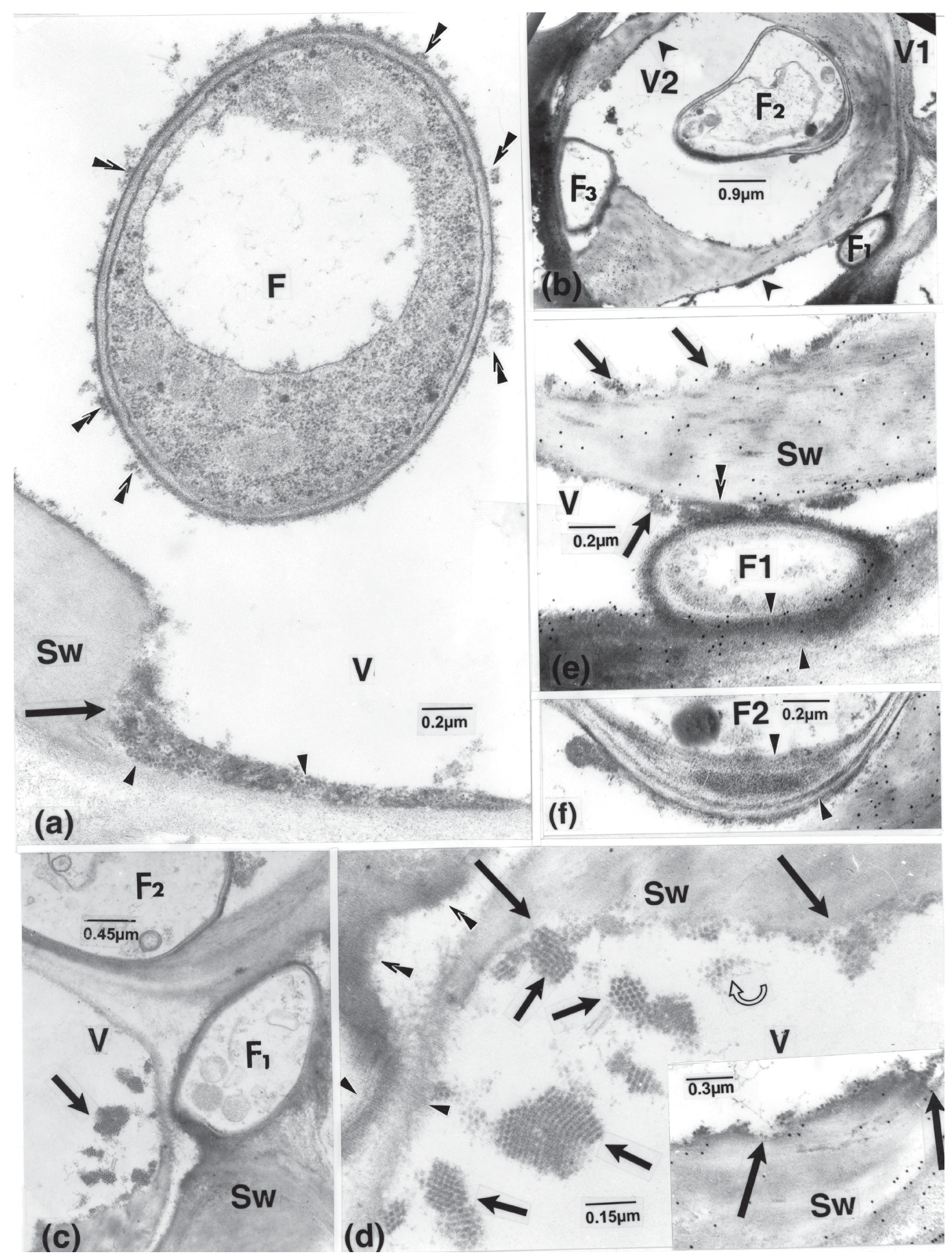

Figure 1. Susceptible cv. dpi, days post-inoculation; F, fungal cell; OP, small opaque particle; Sw, vessel secondary wall; V, vessel element. (a): 2 dpi. Presence of OPs (arrowheads) mixed with fine matter in material lining vessel wall and associated with local alteration (arrow). Similar OPs located close or attached to the fungal cell (superimposed arrowheads). (b): labelling for cellulose. $15 \mathrm{dpi}$. Vessel elements with fungal cells and opaque matter (arrowheads) on the vessel wall. (c): $15 \mathrm{dpi}$. Masses of opaque matter (arrow) and fungal cells in the adjoining paratracheal cell. (d): enlarged portion of the masses in $\mathbf{c}$ and of vessel V1 in b (inset) showing OPs (curved arrow), some aggregated into paracrystalloids (short arrows), and associated fine components (arrowheads); some OPs are associated with locally eroded vessel wall (long arrows). Fine filamentous structures (superimposed arrowheads) extend from the fungal cell into the vessel wall, at points of contact. The vessel wall also has a striate appearance. $(\mathbf{e}, \mathbf{f})$ : enlarged portions of Fig. 1b, of cells F1 and F2, respectively. (e): filamentous structures are extending from inside the cell to within the host wall (arrowheads) and to the opaque matter present on the vessel wall (superimposed arrowheads). Particles are discernible in this and other matter (arrows) bordering the eroded vessel wall. (f): additional wall layers have formed in this portion of the fungal cell, and filamentous structures extend from inside it through the opaque matter included between the layers and through them (arrowheads). 

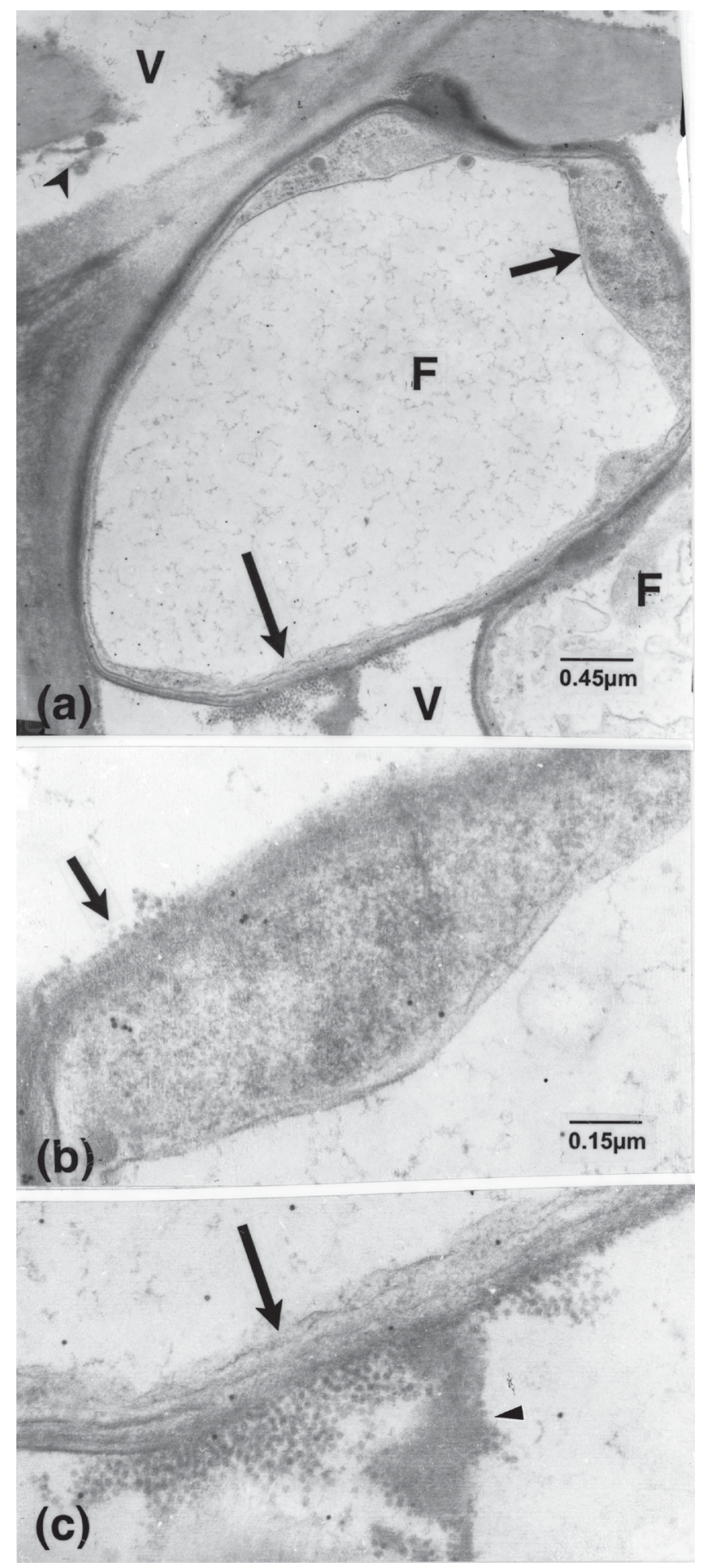

Figure 2. Susceptible cv. F, fungal cell; V, vessel element. (a): $15 \mathrm{dpi}$. Large fungal cells and masses and bands of opaque matter (arrowhead) occur in vessel elements. Portions indicated by short and long arrows, enlarged in b and c, respectively. (b): opaque particles are connected to the fungal wall (arrow), pervaded here and elsewhere by fine filamentous structures. (c): particles, associated with fungal walls (arrow), are also confluent with many in the vessel lumen. Some particles are associated with fine matter in which filamentous structures (arrowhead) can be distinguished. 


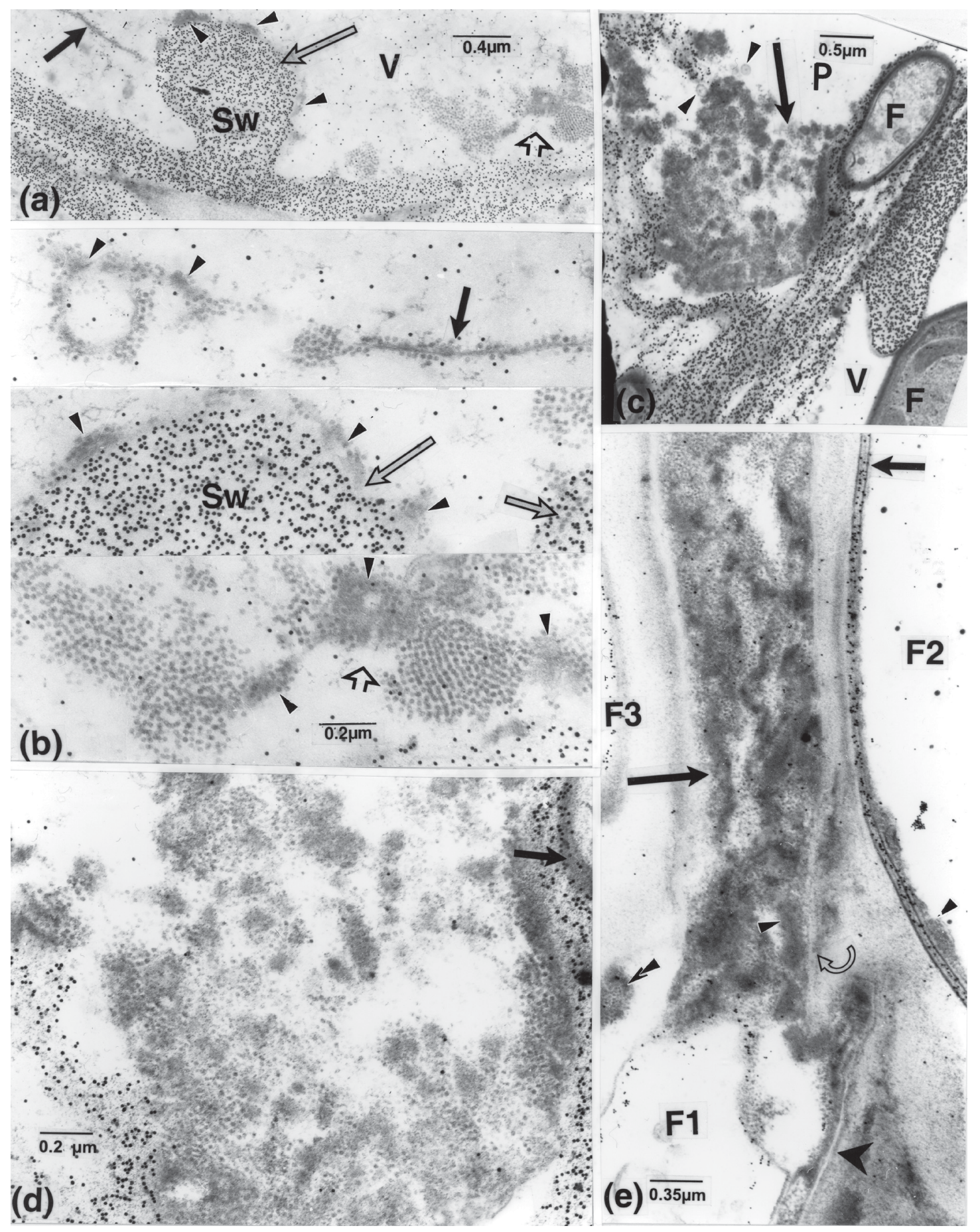

Figure 3. Susceptible cv. F, fungal cell; FM, fine matter; P, parenchyma cell; V, vessel element; Sw, vessel secondary wall. (a): 15 dpi. Labelling for cellulose. Dispersed and aggregated particles and associated matter in a vessel element. (b): enlarged portions from a, of areas indicated by corresponding arrows. Particles are connected to membranous-like structures (short, opaque arrow) or embedded in fine opaque matter (arrowheads), some apposed to the vessel wall; some of the particles are present in the wall itself (short light arrow) distinguishable from the overlaying smaller and more opaque particles of the cellulose probe. (c): $36 \mathrm{dpi}$. Labelling for cellulose. Presence of opaque matter (arrow) and vesicular structures (arrowheads) in altered host walls, together with distinguishable fungal cells. (d): enlarged portion of the mass in c. It shows particles and FM. As shown by labelling, the outer opaque fungal wall has impinged upon the host wall (arrow). (e): labelling for chitin. An element containing opaque particles and FM (long arrow), apparently derived from cell F1, extending into the host cell wall; the intracellular, large cell F2, with its labelled wall delineated by fine bands (short arrow), contains fine components similar to those in this element (small arrowheads). Note: the lucent band, bordering cell F1 (large arrowhead), also delimits particles and FM (which is confluent with that in the element), and the band surrounding this element (curved arrow). Small particles are also included in another opaque mass (superimposed arrowheads), part of a stretch extending across the adjacent cell. 


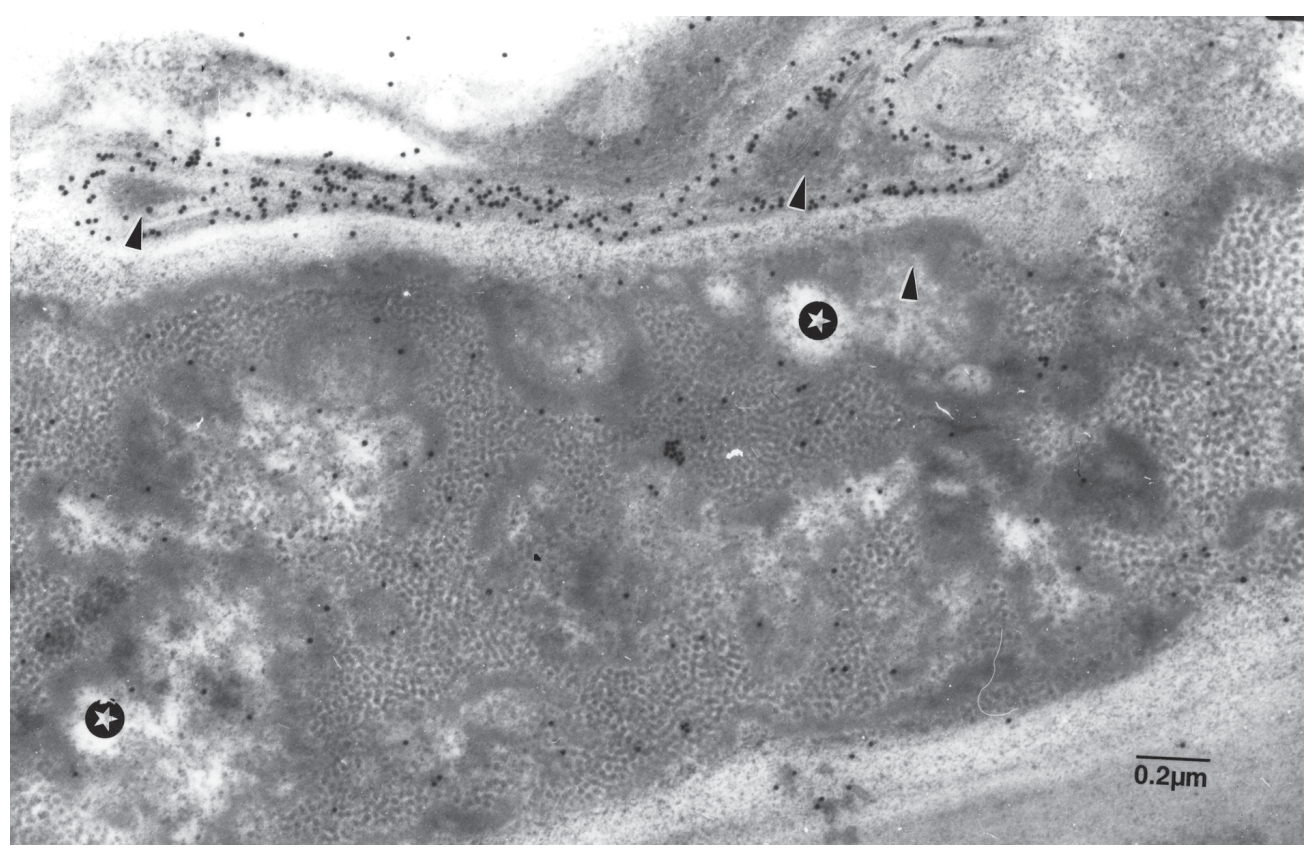

Figure 4. Susceptible cv. 36 dpi. Labelling for chitin. A large mass (stars) containing numerous particles mixed with homogeneous fine matter, extends a long distance intraparietally; the adjoining labelled fungal element contains similar, opaque matter (arrowheads).
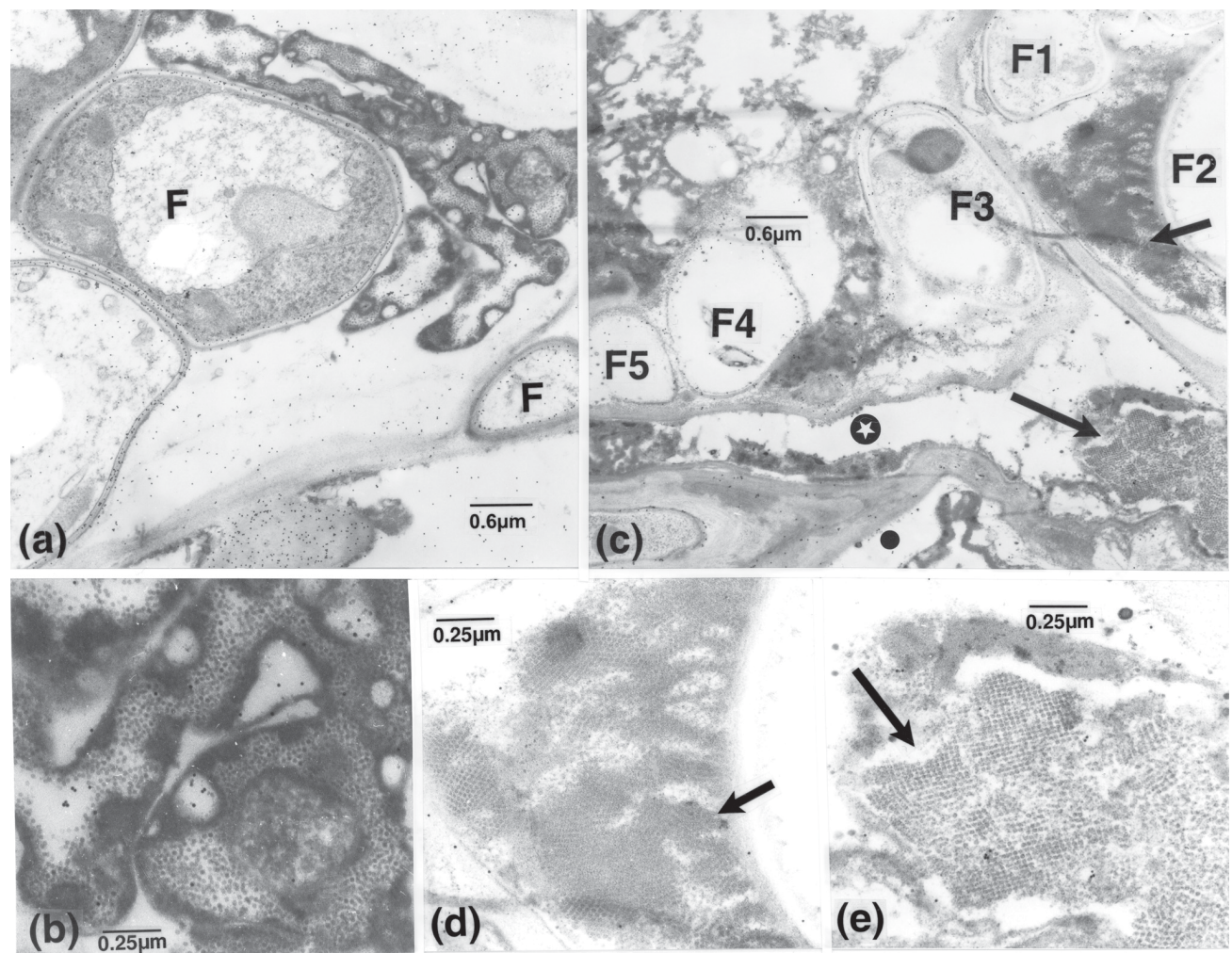

Figure 5. Susceptible cv. (a): 15 dpi. Labelling for chitin. Remnants of host cytoplasm adjoining fungal cells in a paratracheal cell. (b): Enlarged portion from a. Particles, dispersed or seemingly in chains, occur mixed with or bound by masses of opaque components. (c): labelling for pectin with JIM 7. 36 dpi. Masses of matter containing particles (short and long arrows) are bordered by homogeneous matter similar to that extending intercellularly (star) or by fungal cells (F1 and F2). Remnants of host cell content surrounding fungal cells F3-F5 and that in an adjacent cell (dark circle) are seemingly free of particles. (d, e): enlarged portions of c, of the areas shown by a short and long arrow, respectively. Particles are mostly arranged in lattices oriented at diverging angles. 


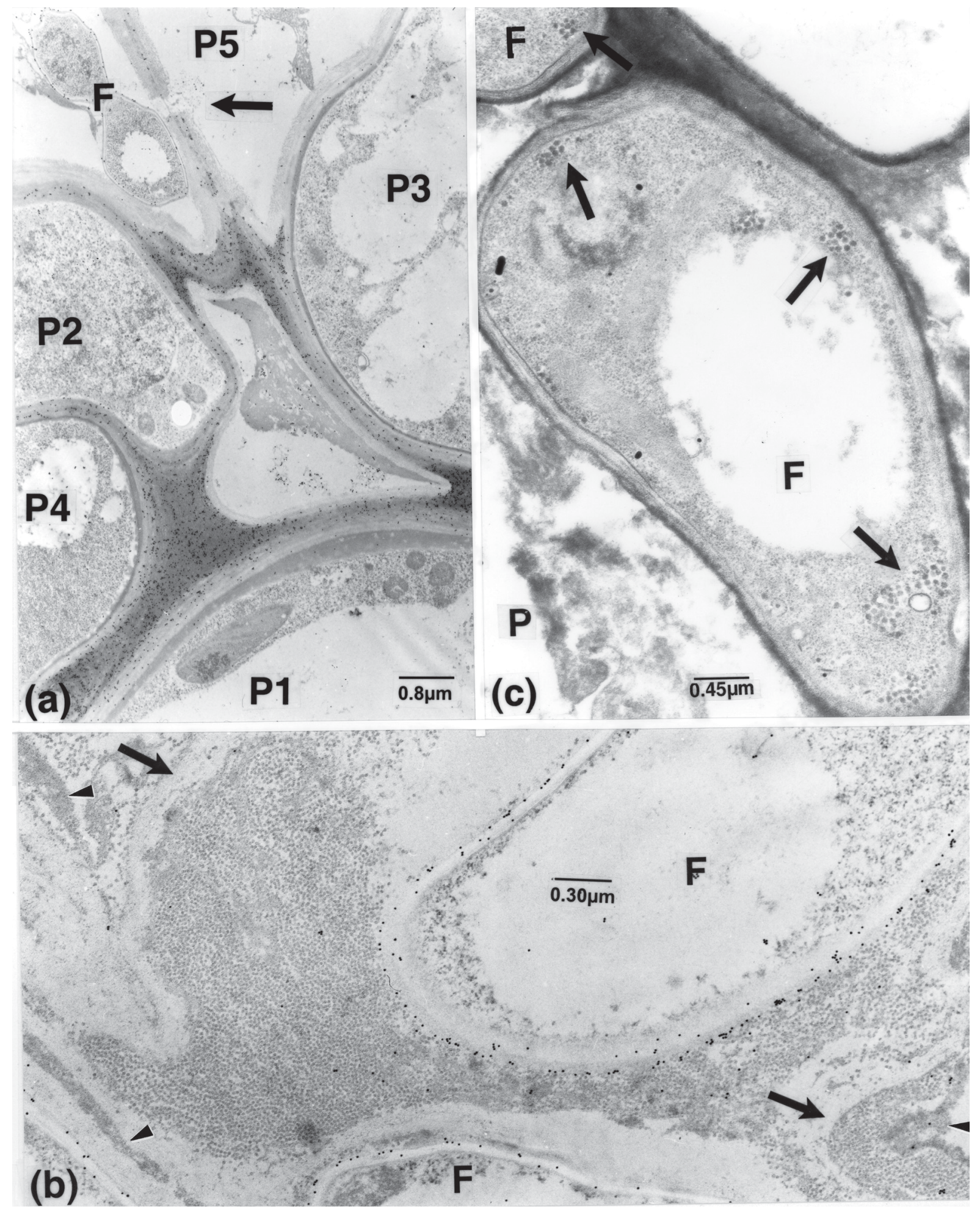

Figure 6. Susceptible cv. F, fungal cell; OPs, small opaque particles; P, parenchyma cell. (a, b): labelling with JIM 5 for pectin. (a): $15 \mathrm{dpi}$. Cell P4, solely contains particles that are similar to OPs in b, shown at a higher magnification; OPs are absent in cells P1P3 having nearly normal content. Note: the altered host cell wall (arrow) is adjacent to a fungal cell. (b): $36 \mathrm{dpi}$. Close to pathogen cells, numerous particles are present in areas including severely altered host cells with distorted or ruptured walls (arrows). Remnants of host cell content, lacking the particles (arrowheads) are distinguishable. (c): fungal cells contain bodies (arrows) which are larger than OPs. 


\section{Resistant plants}

Particles comparable to OPs were few and occasional in vessel lumina of resistant plants (see Ouellette et al. 1999a). Similarly, paracrystalloids and OPs were not detected in vessel lumina in these plants or in cells with normal content and in altered cells remote from colonized cells, in newly differentiated tissue in which collapsed and distorted cells including vessel elements occurred (not illustrated). However, particles were observed in paratracheal cells neighbouring invaded vessel elements or the rarely colonized paratracheal cells (Fig. 7a-d). With rare exceptions, OPs were not observed in host walls (Fig. 7d). The paracrystalloids were again formed of chains of OPs, oriented at diverging angles. Most of these cells contained appositions or new, opaque wall layers, which labelled for cellulose (Fig. 7a, b), or inner lucent, unlabelled layers (Fig. 8a, b). These new layers, which were often separated from the native cell wall layer by masses of seemingly homogeneous, opaque matter (Figs. 7b, 8c), were often eroded in association with these particles, or contained some of them (Fig. $7 b, d)$.

The preceding illustrations of accumulation of the paracrystalloid-forming particles pertained to advanced stages of infection, either in young or older tissue. In Ouellette et al. (2002), an indication was provided that the OPs often accumulated in vacuolarlike areas, surrounded by still normal host cell cytoplasm. The following illustrations expand on this and other particularities of structures occurring in parenchyma cells.

Figures $8 \mathrm{c}$ and $9 \mathrm{a}$ show a ring of OP-like particles, some apparently aggregating, surrounded by recognizable host cell cytoplasm, but in which the particles corresponding to ribosomes are less opaque and mostly smaller and displaying a lucent core. Many cells contained only similar particles with lucent cores (Fig. 9b, c). New wall layers had likewise been deposited in these cells, and filamentous-like structures could be distinguished pervading the native walls (Fig. 9a). In some cells, bordered by invaded vessels or by other seemingly recently deposited, strongly reacting cells, many OP-like particles occurred in lacunar areas, showing links with the surrounding, still relatively normal cell cytoplasm (Fig. 9d, e).

\section{DISCUSSION}

The present observations concerned the occurrence of particles (OPs) and paracrystalloids in carnation plants infected with fusarium wilt. In considering whether these structures were real and free of artefacts, there is no reason to surmise that improper sample fixation and manipulation could have induced the build up of so many particles and paracrystalloids in both the susceptible and resistant plants. As far as it could be determined, these structures and their arrangements have no clear equivalents in the existing literature. A few lines of reasoning may be expressed that eventually may help unravel the nature and mode of formation of these structures. The paracrystalloids formed of OPs did not show a peroxisome-like microbody origin, as do crystals or paracrystalloids which have often been observed in plants, including those affected with wilt diseases (Coffey et al. 1972; Lazarovits and Higgins 1976; Liu and Boyle 1972; Robb et al. 1975) and in etioplasts (Bowman 1994).

A search for reports of similar bodies, unbound and mixed with other cell components, in plants, have yielded only a few examples. Unbound crystalline bodies have likewise been illustrated from plants infected by viruses, for example in oats infected with the blue dwarf virus (Zeyen and Banttari 1972), solely insect-transmitted, or by other pathogens (Fattah and Webster 1984; Sanger et al. 1998). The $28-30 \mathrm{~nm}$ virus particles forming the crystalline bodies described by Zeyen and Banttari (1972) were equally numerous in phloem cells, even intermixed with degraded host tissue, and in this respect may show features analogous to those described here. However, the OPs were smaller, and not detected in cells remote from colonized tissue, occurring even in cell walls in the susceptible cv., a location where virus particles are not expected to occur. Bodies, which at first sight might have corresponded to OPs, were occasionally observed in some pathogen cells, a fact which hinted to the possibility that a plant fungus-transmitted virus might nevertheless have been involved (Hiruki 1994; Temmink et al. 1970). However, these bodies were larger than OPs.

Fattah and Webster (1984) illustrated in nematodeinfected plants paracrystalloid bodies similar to those described here. They suggested that these bodies could have corresponded to protein crystals formed by cuboid subunits. The present paracrystalloids were formed from apparently spherical particles that aggregated into lattices, and therefore do not correspond exactly to known icosehedral forms. Nevertheless, it is interesting to note that cylindrical crystalline structures in cells of nematode-feeding plants have been linked to the nematode-feeding tubes (in Fattah and Webster 1984). Besides the possibility that these bodies represented secretion products from the nematode, they could still have had a link with a fungal pathogen, as a companion infectious agent (Fattah and Webster 1983; Mai and Abawi 1987).

Other types of crystalline bodies have been reported in chloroplasts of fungal-infected plants (Tariq and Jeffries 1985), and considered as Rubisco crystals, composed of enzyme complexes and metals, and possibly analogous to Rubisco crystals formed in an intact system (Taylor et al. 2001).

Concerning the origin and nature of the latticeforming particles themselves, it is important to stress that the same pathogen isolate was used to inoculate both the susceptible and resistant plants. In the susceptible plants, the OPs and paracrystalloids were present at the site of alterations of vessel secondary walls as well as in the compound middle lamellae adjoining invaded cells but were generally absent in the parenchyma cells. In opposition, in the resistant plants, OPs and paracrystalloids abounded in parenchyma cells and were absent elsewhere except for a few questionable cases (as in Fig. 7d, for example). These observations reinforced the previously expressed ones (Baayen et al. 1996; Ouellette et al. 2002) that host wall modifications and deposition of new wall material in host cells were the 

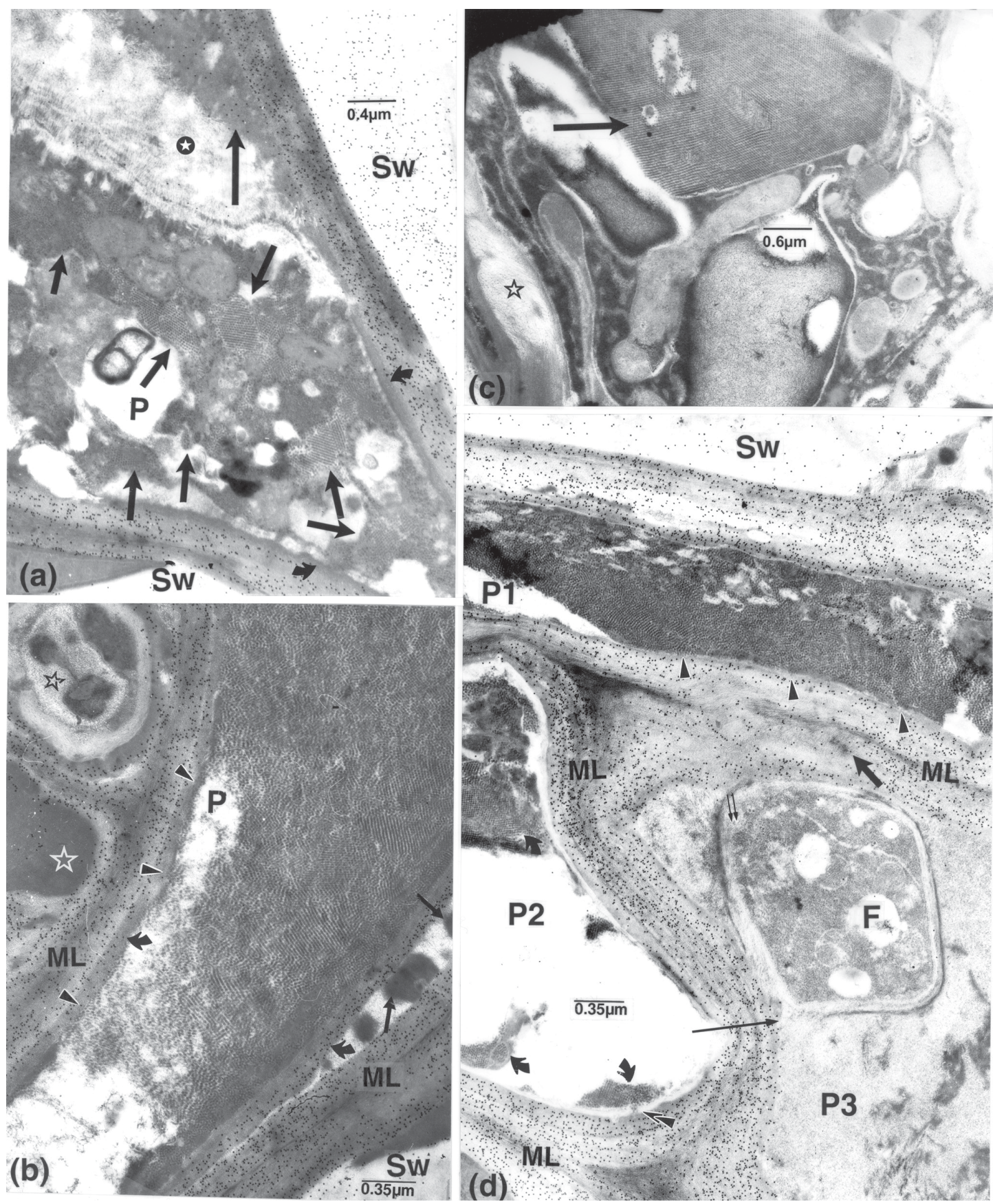

Figure 7. Resistant cv. F, fungal cell; ML, middle lamella, which is often obliterated in these cells; OPs, opaque particles; P, parenchyma cell; SW, vessel secondary wall. $37 \mathrm{dpi}$. (a, b, d): labelling for cellulose. (a): several paracrystalloids of various shapes (short arrows) occur in the moribund content of a P cell adjoining three invaded vessel elements in a primary invasion pocket. A mass of slightly labelled material (long arrow) covering a mass of filamentous components (star) occurs at one end in the cell periphery, and a more compact inner layer, at the other end (curved arrows). (b-d): cells adjoining invaded vessel elements in secondary invasion pockets. (b): the paratracheal cell is filled with diversely oriented lattices of OPs and chains thereof, some clouded by homogeneous matter, and others (arrowheads) impinging upon the inner wall layer (curved arrows) which is only labelled in its outermost portion. Opaque masses (arrows) are present between the additional and the native walls and in the periplasm of an adjacent cell (white contoured star); unusual reactions are noticeable in another cell (dark contoured star). Middle lamellae are mostly indistinct. (c): from newly differentiated tissue. A large crystalline body (arrow), formed of diversely oriented lattices similar to those in a, is part of a medley of components in a paratracheal cell with a cavitated wall (star). (d): numerous OPs, most arranged in lattices, occur in paratracheal cell P1 and adjoining cell P2 (curved arrows). Some OPs occur in the slight notches present in the thin, inner wall in P1 (small arrowheads); others are present across (superimposed arrowheads) the inner lucent layer in cell P2. In cell P3, a fungal cell, filled with some fine filamentous-like components with some extending through its wall (paired, small arrows), is surrounded by similar and more compact material. Similar structures (left of the thick arrow), distinguishable in the altered region of the middle lamella, reach the fungal cell; a reduction of labelling for cellulose occurs in this region. The short, dark arrow points to opaque particles in the same region, and the thin arrow, to a breaching of the host wall, next to the fungal cell. 


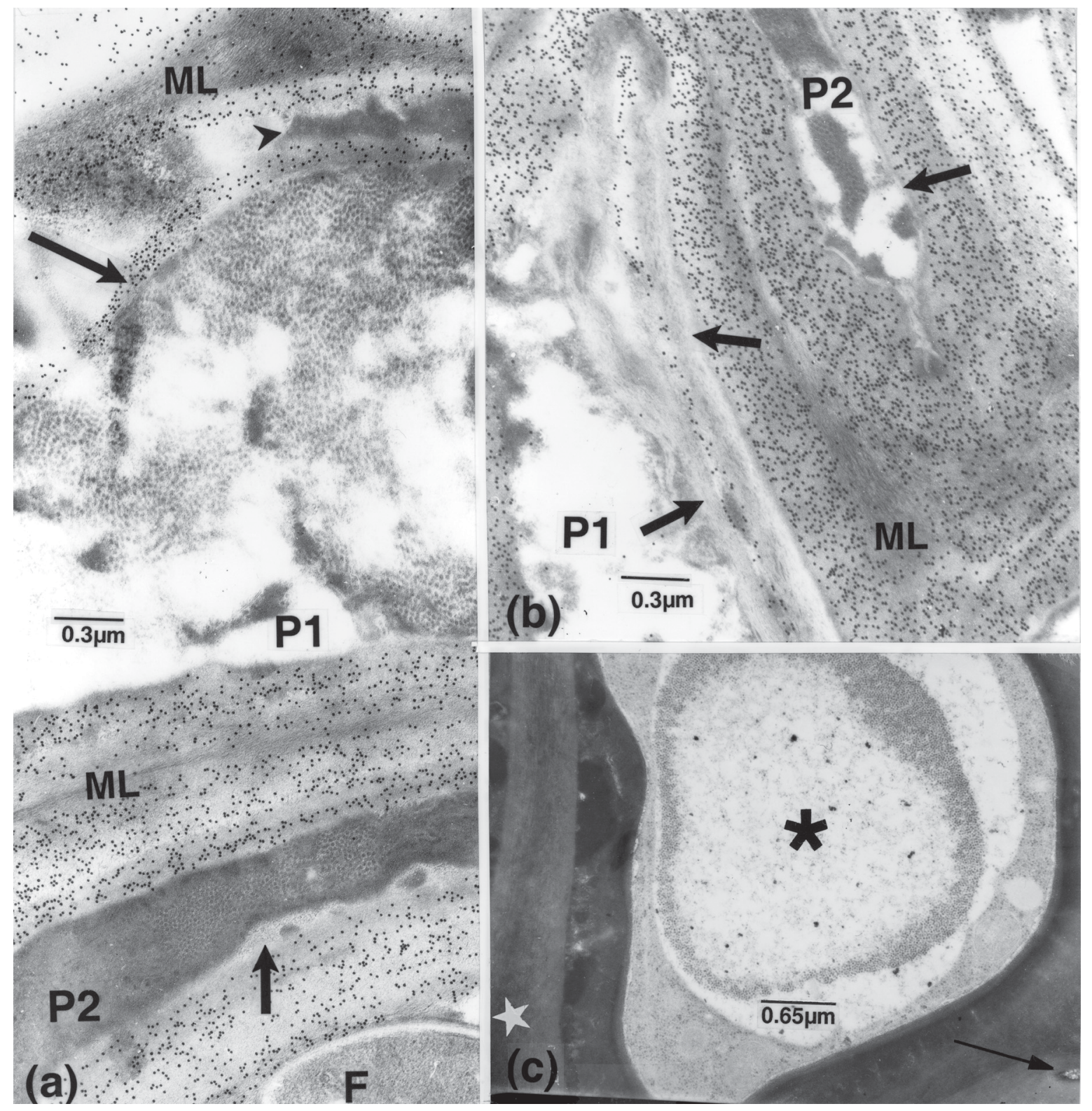

Figure 8. Resistant cv. F, fungal cell; OPs, opaque particles; $P$, parenchyma cell; ML, middle lamella. Presence of numerous OPs, many aggregated, in cells having deposited new, inner layers, next to invaded vessel elements. Middle lamellae are obliterated or altered. (a-c): tissue in, or close to, secondary invasion pockets, $37 \mathrm{dpi}$; a and b, labelling for cellulose. (a): OPs are present throughout cell P1 and in patches in paratracheal cell P2 (next to arrow). In cell P1, the labelled, mostly lucent, inner layer (long arrow) is separated from the native layer by opaque material (arrowhead). In cell P2, the inner layer (short arrow) is unequally thick and unlabelled, containing masses of opaque matter, on the side facing the vessel element. (b): cells containing an inner, lucent layer (arrows); it is thick in cell P1, seemingly deposited following a retraction of the cell content, and thin in cell P2 lining thickened walls. (c): $8 \mathrm{dpi}$. OPs contour a vacuole-like area (asterisk) in a paratracheal cell, with thick, heterogeneous appositions, adjoining an invaded vessel element (arrow). 

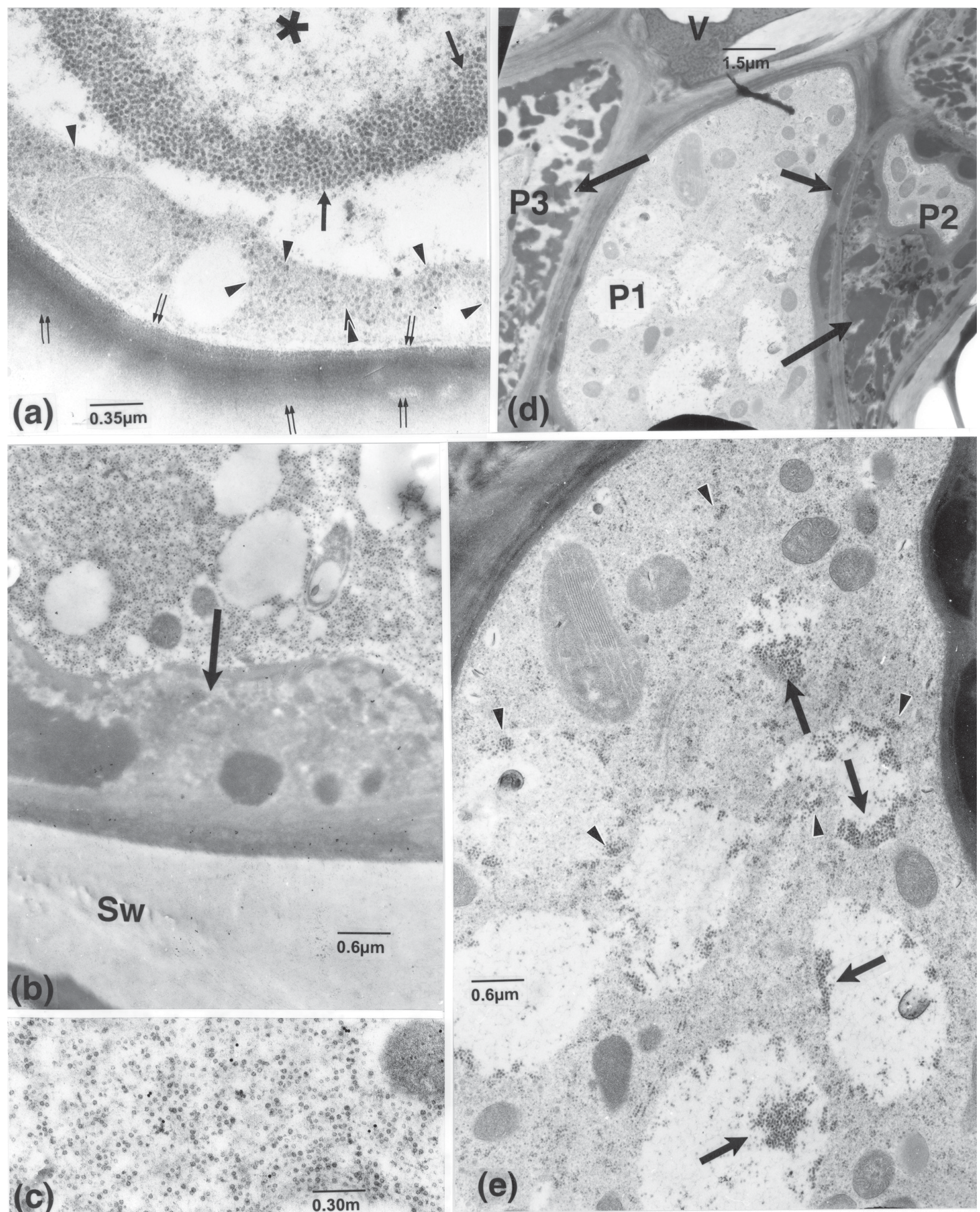

Figure 9. Resistant cv. P, parenchyma cell; Sw, vessel secondary wall; V, vessel element. (a): enlarged area from Fig. 8c. Many OPs occur in chains or groups (arrows), interconnected by fine material. These are more opaque and larger than the ribosomal particles, some with lucent cores (arrowheads) and also mixed with fine material (superimposed arrowheads), in the surrounding cytoplasm. The host cell wall appears to be pervaded by fine, filamentous structures (paired, small arrows) reaching the cell periphery. (b): a paratracheal cell with a thick wall apposition (arrow) mostly contains particles similar to OPs and some organelle remnants. (c): an enlarged portion of $\mathbf{b}$. The particles, mixed with fine material, display lucent cores (compare with a). (d): next to an invaded vessel element, cell P1, with nearly normal content, has an inner new wall layer locally separated from the native wall by masses of opaque matter (short arrow), as are also cells P2 and P3 (long arrows). (e): enlarged portions of cell P1, showing the presence of numerous, small OP-like particles in lacunar areas (arrows) or in the cytoplasm itself (arrowheads); ribosomes in the surrounding cytoplasm are smaller and less opaque. 
main factors impeding extensive pathogen ingress in the resistant plant. In this plant also, in an exact reverse situation with the susceptible plant, was the abundance of paracrystalloids and associated OPs in parenchyma cells and their lack in vessel lumina. One may thus suspect that the OPs, although structurally alike in both hosts, might not be exactly of the same nature, due to putative interaction with host cell content(s) in one case, but seemingly not in the other. In both instances, however, the same triggering action might have been involved. Indeed, both have in common the filamentous-like structures which extended from pathogen cells into the surrounding medium, in vessel lumina and host walls, mainly the pit membranes in the case of resistant plants, reaching the cell content.

Similar structures also appeared to extend into the opaque matter ensuing from fungal cells. Although the OPs were not detected in that matter in vessel lumina in the resistant plants, they were associated with it in parenchyma cells. As shown here and in previous reports (Charest et al. 2004; Ouellette and Rioux 1993; Ouellette et al. 1995, 1999a, 1999b, 2001, $2002,2004 a, 2004 b, 2004 c, 2004 d$ ), the release of fungal components would also be facilitated by modifications or the local absence of fungal walls. In elms, eggplant, and staghorn sumac, large masses and long stretches of opaque matter also occur, related to tissue alterations, and small particles are likewise connected to the coating as well as to fungal cells. Overall, it is difficult to visualize how the abundance of OPs in lumina of mature vessel elements could have been formed directly by the host. Similarly, the prolific occurrence of these OPs and paracrystalloids in parenchyma cells in resistant plants can hardly be ascribed to a boosted production of ribosomes, also different from the particles, to a plant virus that would develop independently of host cell cytoplasm (in vessels and host walls), or seemingly subsequently to the deposition of new wall layers in xylem cells and in the absence of intact organelles. In fact, these particles have not been observed in nuclei.

Whether in conjunction with the presently described structures or with other elements present on vessel walls, as described in the companion paper (Ouellette et al. 2004a), the host disturbances appear to be primarily related to the presence of fine filamentous structures and opaque matter extending from pathogen cells. In this perspective, many fungi have been shown to produce structures termed "fungal fimbriae" (Poon and Day 1975) that extend from the fungal cell into the surrounding medium, as units containing RNA and collagen (Celerin et al. 1994, 1996). Present observations may also concur with reports that in some bacteria, ribosomes may form crystals (Clark et al. 1982; Sutcliffe 2004) or "special protein-DNA cocrystals" (Frenkiel-Krispin and Minsky 2002).

In the susceptible carnation plants, the coating may thus occur either as OP-containing matter, as layers labelling for chitin, depending on the stage of infection (Ouellette et al. 2004a), or as layers of compact opaque matter. These constituents all have in common their association with vessel wall alterations, and the opaque matter in each may be congruous. The general occurrence of the features described shows their importance but, obviously, pursuing this study with other techniques, for example the production and use of other specific probes, would be commendable to discriminate more widely between host and pathogen components, particularly regarding the extraneous material present in vessel lumina.

\section{ACKNOWLEDGMENTS}

In addition to the contributors mentioned in the companion paper, we are indebted to Dr. Alain Asselin, FSAA, Université Laval, and to Dr. Michel Cusson, Laurentian Forestry Centre, for their valuable criticism and suggestions in the preparation of the manuscript.

\section{REFERENCES}

Baayen, R.P., G.B. Ouellette, and D. Rioux. 1996. Compartmentalization of decay in carnations resistant to Fusarium oxysporum f.sp. dianthi. Phytopathology 86 : 1018-1031.

Bowman, J.B. (ed.) 1994. Arabidopsis, an atlas of morphology and development. Springer-Verlag, New York. Pages 4449.

Celerin, M., D.E. Laudenbach, J.B. Bancroft, and A.W. Day. 1994. Evidence that fimbriae of the smut fungus Microbotryum violaceum contain RNA. Microbiology $140: 2699-2704$

Celerin, M., J.M. Ray, N.J. Schisler, A.W. Day, W.G. StetlerStevenson, and D.E. Laudenbach. 1996. Fungal fimbriae are composed of collagen. EMBO J. $15: 4445-4453$.

Charest, P.M., G.B. Ouellette, P. Blais, and H. Chamberland. 2004. Irregular growth forms and cell wall modifications, polygalacturonase detection, and endocell formation in Fusarium oxysporum f.sp. radicis-lycopersici infecting tomato plants, as studied ultrastructurally and cytochemically. Mycol. Prog. 3 : 137-150.

Clark, M.W., K. Leonard, and J.A. Lake. 1982. Ribosomal crystalline arrays of large subunits from Escherichia coli. Nature $216:$ 999-1001.

Coffey, M.D., B.A. Palevitz, and P.J. Allen. 1972. Ultrastructural changes in rust-infected tissues of flax and sunflower. Can. J. Bot. $50: 1485-1492$.

Fattah, F., and J.M. Webster. 1983. Ultrastructural changes caused by Fusarium oxysporum f.sp. Iycopersici in Meloidogyne javanica induced giant cells in Fusarium resistant and susceptible cultivars. J. Nematol. 15 : 128-135.

Fattah, F., and J.M. Webster. 1984. Fine structure of the giant cells induced by Meloidogyne javanica in lima bean. Can. J. Bot. 62 : 429-436.

Frenkiel-Krispin, D., and A. Minsky. 2002. Biocrystallization: a last-resort survival strategy in bacteria. ASM News $68: 277-283$.

Hiruki, C. 1994. Multiple transmission of plant viruses by Olpidium brassicae. Can. J. Plant Pathol. 16 : 261-265.

Lazarovits, G., and V.J. Higgins. 1976. Ultrastructure of susceptible, resistant, and immune reactions of tomato to races of Cladosporium fulvum. Can. J. Bot. 54 : 235249.

Liu, K.-C., and J.S. Boyle. 1972. Intracellular morphology of two tobacco mosaic virus strains in, and cytological responses of, systemically susceptible potato plants. Phytopathology 62 : 1303-1311.

Mai, W.F., and S.S. Abawi. 1987. Interactions among rootknot nematodes and fusarium wilt fungi on host plants. Annu. Rev. Phytopathol. 25 : 317-338. 
Ouellette, G.B., and R.P. Baayen. 2000. Peculiar structures occurring in vessel walls of the susceptible carnation cultivar Early Sam infected with Fusarium oxysporum f.sp. dianthi. Can. J. Bot. 78 : 270-277.

Ouellette, G.B., and D. Rioux. 1993. Alterations of vessel elements and reactions of surrounding tissues in the DED syndrome. Pages 255-292 in M.B. Sticklen, and J.L. Sherald (eds.), Dutch elm disease research: cellular and molecular approaches. Springer-Verlag, New York.

Ouellette, G.B., N. Méthot, H. Chamberland, C. Côté, and J.-G. Lafontaine. 1995. Cytology of irregular growth forms of Ophiostoma ulmi and Ophiostoma novo-ulmi growing through millipore membranes and sterilized elm wood sections. Can. J. Microbiol. 41 : 1095-1110.

Ouellette, G.B., R.P. Baayen, M. Simard, and D. Rioux. 1999a. Ultrastructural and cytochemical study of colonization of xylem vessel elements of susceptible and resistant Dianthus caryophyllous by Fusarium oxysporum f.sp. dianthi. Can. J. Bot. 77 : 644-663.

Ouellette, G.B., H. Chamberland, A. Goulet, M. Lachapelle, and J.-G. Lafontaine. 1999b. Fine structure of the extracellular sheath and cell walls in Ophiostoma novoulmi growing on various substrates. Can. J. Microbiol. 45 : 582-597.

Ouellette G.B., R.P. Baayen, L. Bernier, H. Chamberland, P.M. Charest, D. Rioux, and M. Simard. 2001. Chitin: to be or not to be in some ascomycetous fungi. Pages 7989 in R.A.A. Muzzarelli (ed.), Chitin Enzymology 2001. Atec Edizioni, Grottammare, Italia.

Ouellette, G.B., R.P. Baayen, M. Simard, and D. Rioux. 2002. Reactions of paratracheal cells of resistant and susceptible carnation (Dianthus caryophyllus) cultivars to vascular invasion by Fusarium oxysporum f.sp. dianthi. New Phytol. $156: 113-128$.

Ouellette, G.B., R.P. Baayen, D. Rioux, and M. Simard. 2004a. Peculiar ultrastructural characteristics of fungal cells and of other elements apposed to and in vessel walls in plants of a susceptible carnation cultivar, infected with Fusarium oxysporum f.sp. dianthi race 2. Phytoprotection $85: 121-138$.

Ouellette, G.B., R.P. Baayen, H. Chamberland, M. Simard, D. Rioux, and P.M. Charest. 2004b. Cytochemical labelling for fungal and host components in plant tissues inoculated with fungal wilt pathogens. Microsc. Microanal. $10: 449$ 461.
Ouellette, G.B., D. Rioux, M. Simard, and M. Cherif. 2004c. Ultrastructural and cytochemical studies of host and pathogens in some fungal wilt diseases: retro- and introspection towards a better understanding of DED. In L. Gil, A. Solla, and G.B. Ouellette (eds.), New Approaches to Elm Conservation. Investig. Agrar: Sist. Recur. For. 13 : 119-145.

Ouellette, G.B., D. Rioux, M. Simard, H. Chamberland, M. Cherif, and R.P. Baayen. 2004d. Ultrastructure of the alveolar network and its relation to coating on vessel walls in elms infected by Ophiostoma novo-ulmi and in other plants affected with similar wilt diseases. In L. Gil, A. Solla, and G.B. Ouellette (eds.), New Approaches to Elm Conservation. Investig. Agrar: Sist. Recur. For. 13 : 147-160.

Poon, H., and A.W. Day. 1975. "Fimbriae" in the fungus Ustilago violacea. Nature $250: 648-649$.

Robb, J., L. Busch, and B.C. Lu. 1975. Ultrastructure of wilt syndrome caused by Verticillium dahliae. I. In chrysanthemum leaves. Can. J. Bot. 53 : 901-913.

Sanger, M., U.E. Järlfors, and S.A. Ghabrial. 1998. Unusual cytoplasmic inclusions induced in tobacco by peanut stunt virus subgroup II strains map to RNA3. Phytopathology 88 : 1192-1199.

Sutcliffe, J.A. 2004. The search for new antibiotics targeting the 50 S ribozyme. ASM News $70: 513-519$.

Tariq, V.-N., and P. Jeffries. 1985. Changes occurring in chloroplasts of Phaseolus following infection by Sclerotinia: a cytochemical study. J. Cell Sci. 75 : 195205

Taylor, T.C., A. Backlund, K. Bjorhall, R.J. Spreitzer, and I. Andersson. 2001. First crystal structure of Rubisco from a green alga, Chlamydomonas reinhardtii. J. Biol. Chem. $276: 48159-48164$

Temmink, J.H.M., R.N. Campbell, and P.R. Smith. 1970. Specificity and site of in vitro acquisition of tobacco necrosis virus by zoospores of Olpidium brassicae. J. Gen. Virol. 9 : 201-213.

Zeyen, R.J., and E.E. Banttari. 1972. Histology and ultrastructure of oat blue dwarf virus infected oats. Can. J. Bot. $50: 2511-2519$. 